\title{
Testosterone Delivery Using Glutamide-based Complex High Axial Ratio Microstructures
}

\author{
Alex S. Goldstein, ${ }^{\mathrm{a}}$ John K. Amory, ${ }^{\mathrm{b}}$ Stephanie M. Martin, ${ }^{\mathrm{c}}$ Chris Vernon, ${ }^{\mathrm{a}}$ \\ Alvin Matsumoto ${ }^{\mathrm{b}}$ and Paul Yager ${ }^{\mathrm{c}, *}$ \\ ${ }^{a}$ Departments of Chemistry and Biochemistry, University of Washington, Box 351700, Seattle, WA 98195-1700, USA \\ ${ }^{\mathrm{b}}$ Geriatric Research Education and Clinical Center and General Internal Medicine Section (S-182-GRECC and S-111-GIMC), \\ VA-Puget Sound Health Care System, University of Washington, 1660 S. Columbian Way, Seattle, WA 98108, USA \\ ${ }^{\mathrm{c}}$ Molecular Bioengineering Program, Department of Bioengineering, University of Washington, Box 352255, Seattle,
} WA 98195-2255, USA

Received 14 September 2000; accepted 26 April 2001

\begin{abstract}
Complex high axial ratio microstructures (CHARMs) were evaluated for delivery of testosterone in vivo. Methods to incorporate testosterone included noncovalent mixing and covalent attachment of testosterone to the lipid to form a prodrug monomer. When prepared by covalent attachment, testosterone-loaded CHARMs were resistant to in vitro spontaneous hydrolysis; when injected into rats, testosterone was released with biphasic kinetics consisting of a burst followed by a much slower phase. Some CHARM material associated with testosterone persisted at the site of injection for at least 9 days. (C) 2001 Elsevier Science Ltd. All rights reserved.
\end{abstract}

\section{Introduction}

Estimates from the latest pharmaceutical marketing surveys suggest that there exists a need for long-term testosterone therapy in about 5 million hypogonadal men; only 250,000 are currently being treated. Current delivery methods are far from ideal. ${ }^{1}$ These methods include intramuscular injections of testosterone esters every 2-3 weeks, ${ }^{2,3}$ daily application of testosterone patches $^{4}$ (which may cause skin irritation rashes and adhere poorly) or gels, and oral forms of testosterone (which are ineffective and may cause liver damage and thus are not used for long-term therapy). ${ }^{5}$ Recently, implants and microspheres have been used ${ }^{6-9}$ but an ideal, long-term continuous release delivery system has not been identified.

This paper reports initial attempts to develop a method of long-term testosterone delivery based on non-liposomal self-assembled surfactant supramolecular assemblies. These microstructures, which include tubules, helices, twisted ribbons and cochleate cylinders, are

*Corresponding author. Tel.: +1-206-543-6126; fax:+1-206-5436124; e-mail: yagerp@washington.edu collectively called complex high axial ratio microstructures (CHARMs). In previous studies, others have used cochleate cylinders and the lumen space of lipid tubules for the controlled release of a variety of therapeutic agents. ${ }^{10-13}$ Bisalkyl glutamide-based lipids have been shown to self-assemble into CHARMs. ${ }^{14-16}$ Tight crystalline packing of the lipid in CHARMs appears to limit the rate of spontaneous or enzymatic release. ${ }^{14,17,18}$ The rate of drug release may be rationally manipulated by controlling lipid solubility or location of a cleavable tether. ${ }^{18}$ If testosterone or its ester could be incorporated into a CHARM, a depot consisting of this material might be suitable for long-term delivery of the hormone.

To this end, three approaches to incorporate testosterone into CHARMs were studied. It has been shown that binary lipid supramolecular complexes with defined morphologies may be formed in which a non-CHARM forming lipid is co-precipitated with a CHARM-forming lipid. ${ }^{19-22}$ In the first approach, testosterone or a testosterone ester would be noncovalently incorporated into appropriate microstructures formed from a host lipid. In the second approach, testosterone covalently replaced either of the alkyl chains of a host CHARMforming lipid. In the third approach (and the one 
considered least likely to succeed), testosterone was covalently attached to a core CHARM-forming lipid as a headgroup.

\section{Results and Discussion}

Initially, testosterone $(\mathrm{T})$ was co-precipitated with either didodecylglutamide (E12) or $N$-acetyldidodecylglutamide (AcE12). Various ratios of glutamide and testosterone (1:1-1:7 T:E12 or T:AcE12) were intimately mixed in DMF or EtOH. Precipitates were formed by adding water and left at room temperature. In all cases, the resultant CHARMs excluded the testosterone as determined by ${ }^{1} \mathrm{H}$ NMR. Under these conditions, the steroid was not observed to assume a regular morphology.

It is well known that a steroid nucleus is inflexible, occupies a cross-sectional area equivalent to two hydrocarbon chains, and perturbs bilayer packing. Furthermore, molecular modeling showed that the longest dimension of testosterone is roughly $3 \AA$ shorter than a fully extended didodecylglutamide alkyl chain. The steroid is not long enough to span one-half of the lipid bilayer microstructure, thus potentially perturbing the lipid packing. Modeling indicated that two additional carbons attached to $\mathrm{T}$ would add the required 3 $\AA$; therefore, an acetate group, which also masks the polar hydroxyl moiety, was selected to overcome the packing deficiency. As an additional biological bonus, the in vivo half-life of testosterone esters are known to be greater than that of testosterone. ${ }^{2,23}$ Testosterone acetate (AcT) and glutamide amphiphiles (1:1-1:7 AcT:E12 or 1:1-1:7 AcT:AcE12) were co-precipitated. Again, NMR analysis of the pelleted microstructures indicated that the steroid was excluded from the CHARMs formed by the glutamate-based amphiphiles.

In the second approach, testosterone was conjugated to the core glutamide amphiphile in place of an alkyl hydrocarbon sidechain (Scheme 1). This synthesis was executed so that testosterone was attached to either the sidechain carboxylic acid or the C-terminus. To accomplish this, a commercially available $N$-Boc-glutamic acid derivative with one carboxylic acid functionality protected as a $t$-butyl ester and the other activated as a $N$ hydroxysuccinimidyl ester (1a or $\mathbf{1 b}$ ) was reacted with dodecylamine to generate the protected monoalkyl glutamide. The protecting groups were removed by treatment with trifluoroacetic acid and the amine protected as a $t$-butyl carbamate. Testosterone was attached via an ester linkage using carbodiimide and the final product generated by revealing the amine upon treatment with trifluoroacetic acid (2a or $\mathbf{2 b})$. The hydrolysis of the ester linkage, the most labile, would release pure hormone.

The testosterone-glutamide side-chain conjugates were precipitated independently or as mixtures with E12 or AcE12 (1:1-1:7) from either DMF or EtOH. In all cases, if CHARMs formed, the testosterone conjugates were excluded from the supramolecular assemblies.

In the third approach, testosterone was attached as a headgroup to bistetradecanoyl glutamide amphiphile using a succinate tether (Scheme 2). This was considered a 'risky' approach because it was anticipated that the hydrophobic nature of $\mathrm{T}$ would cause it to insert itself into the bilayer and thereby interfere with the hydrogen bonding expected in the CHARM headgroup. A longer bisalkyl hydrocarbon glutamide compound and<smiles>[R]C(=O)CCC(N=O)C([R])=O</smiles>

1) dodecyl amine

2) TFA

3) $(\text { Boc })_{2} \mathrm{O}$ TEA 4) Testosterone DCC, DMAP 5) TFA<smiles>[R2]C(=O)CCC(N)C([R])=O</smiles>

1a) $R_{1}=O-t B u, R_{2}=O S u$

1b) $R_{1}=O S u, R_{2}=O-t B u$

2a) $\mathrm{R}_{1}=$ testosterone, $\mathrm{R}_{2}=\mathrm{N}\left(\mathrm{CH}_{2}\right)_{11} \mathrm{CH}_{3}$

2b) $\mathrm{R}_{1}=\mathrm{N}\left(\mathrm{CH}_{2}\right)_{11} \mathrm{CH}_{3}, \mathrm{R}_{2}=$ testosterone

Scheme 1.

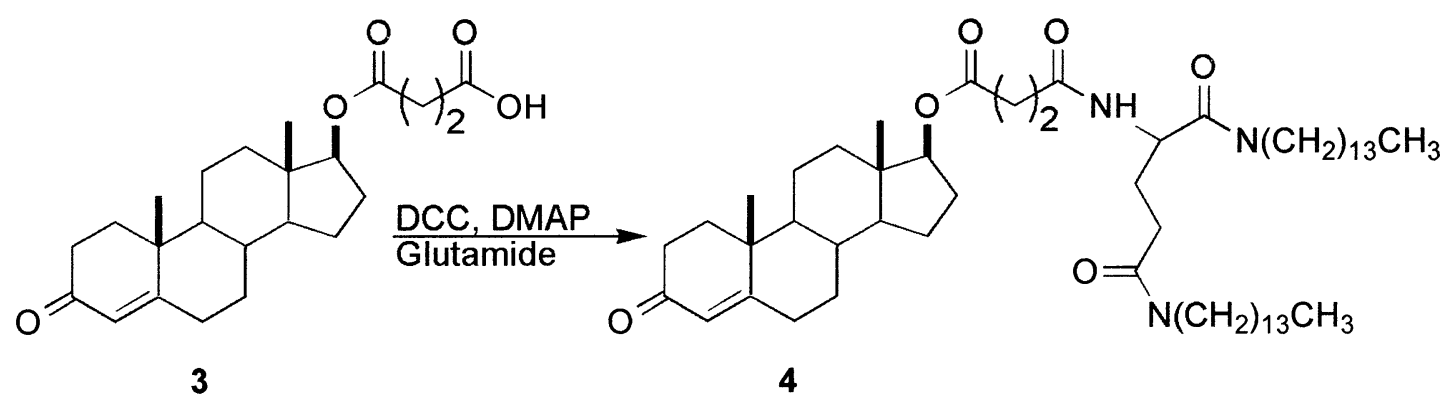

Scheme 2. 
four-carbon tether were used because of their availability in the laboratory. The ester that connects $T$ to the core lipid is the most labile linkage and should hydrolyze before any of the amides, thus releasing testosterone. Testosterone-succinate ${ }^{24}$ (3) was coupled to the glutamide using carbodiimide to yield the final product (4), T4E14.

Despite its hydrophobic headgroup, T4E14 independently formed CHARMs when precipitated from either DMF or EtOH by the addition of water (Fig. 1). As can be seen from the transmission electron micrographs, the DMF cast material appears ribbon-like, whereas that precipitated from EtOH is rod-like. A dependence of CHARM morphology on the formation conditions is not uncommon. ${ }^{19,25-29}$ Freeze fracture electron microscopy revealed that the EtOH-derived T-CHARM material was neither cochleate nor hollow but composed of stacked ribbons (Fig. 2). Such structures have been reported in the literature. ${ }^{30,31}$

The EtOH-derived T4E14 CHARMs were further assessed for physical stability to determine their suitability for in vivo use. First, the hydrocarbon chain order-disorder transitions were measured. DSC indicated a $T_{\mathrm{m}}$ of $82^{\circ} \mathrm{C}$ in $100 \mathrm{mM} \mathrm{NaH}{ }_{2} \mathrm{PO}_{4}$ buffer at $\mathrm{pH}$
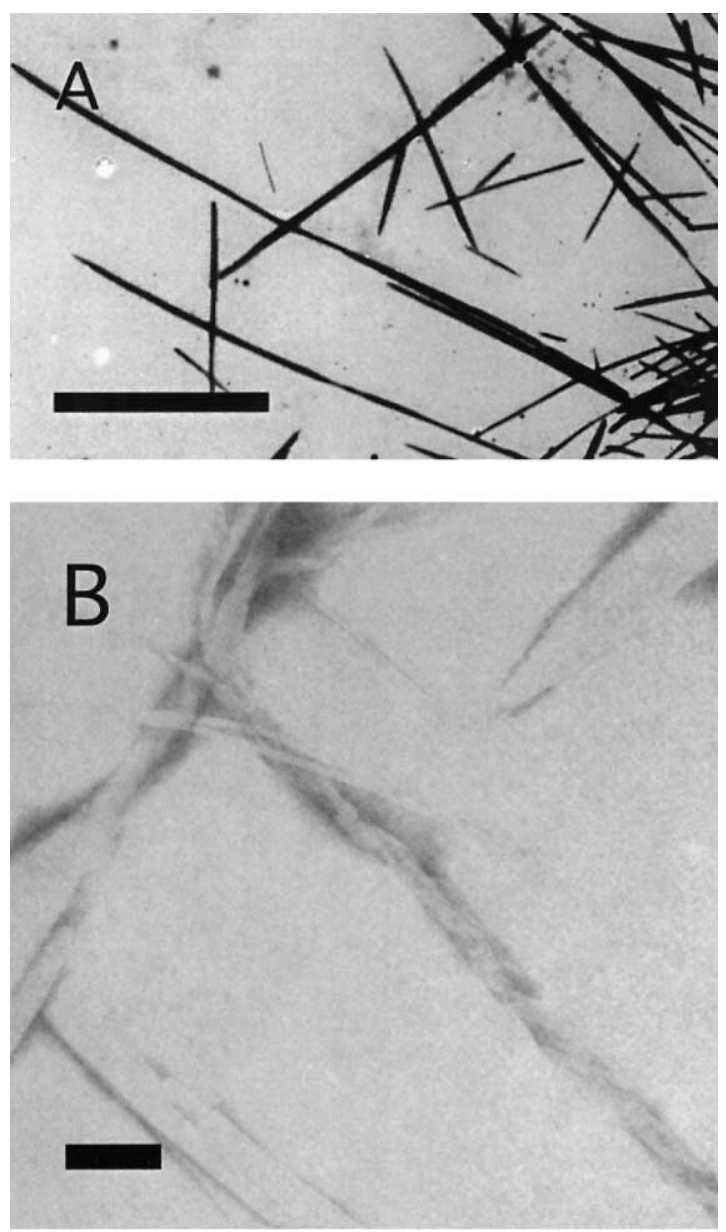

Figure 1. Negatively stained transmission electron micrographs of $\mathrm{T}$ CHARM material after casting from (A) $\mathrm{EtOH} / \mathrm{H}_{2} \mathrm{O}$ (scale bar $1 \mu \mathrm{m}$ ), (B) $\mathrm{DMF} / \mathrm{H}_{2} \mathrm{O}$ (scale bar $50 \mathrm{~nm}$ ).
7.4. This implied that the material should remain in its original crystalline morphology when injected into an animal. Next, the in vitro hydrolytic susceptibility of T4E14 was evaluated.

CHARMs were suspended in either $100 \mathrm{mM} \mathrm{NaH}{ }_{2} \mathrm{PO}_{4}$ buffer $\mathrm{pH} 9.2(1.30 \mathrm{mM}$ T-CHARM) or PBS $\mathrm{pH} 7.4$ (1.30 and $0.13 \mathrm{mM} \mathrm{T-CHARM} \mathrm{with} \mathrm{mild} \mathrm{agitation)} \mathrm{and}$ incubated at $37^{\circ} \mathrm{C}$. The alkaline $\mathrm{pH} 9.2$ should accelerate the base-catalyzed hydrolysis over what would be expected at physiological $\mathrm{pH}$ 7.4. At various times the assemblies were pelleted, supernatant removed, and the residues dried under vacuum. T4E14 and its ester hydrolysis products, $\mathrm{T}$ and $\mathrm{N}$-succinoyl didodecyl glutamide (4E14), are insoluble in water. The dried CHARMs were dissolved in $\mathrm{CDCl}_{3}$ and examined by ${ }^{1} \mathrm{H}$ NMR to determine the extent of hydrolysis. In all cases there was less than 5\% hydrolysis (limit of detection) even after incubating for 32 days. The $\mathrm{pH}$ and buffer concentrations were invariant within this time frame. These experiments showed T4E14 to be extremely robust with respect to base-catalyzed hydrolysis, which implies that in the CHARM the ester group is not exposed to hydrolytic conditions.

\section{In vivo testosterone release}

Study 1. Four groups composed of six animals each were used in this study. The first three groups were castrated and received subcutaneous injections of $10.0 \mathrm{mg}$ T-CHARM material, $1.0 \mathrm{mg}$ T-CHARM material, or $10.0 \mathrm{mg}$ Me4E14. The last group was mockcastrated and received subcutaneous injections of buffer. In vivo testosterone levels were evaluated from serum collected from tail bleeds on days $2,6,13,20$, and 27 using an immunofluorimetric assay (DELFIA ${ }^{32}$ ). Initially, the animals' normal testosterone levels were measured (precastration). After recovering for one week after castration, the blood serum levels for the castrated animals were below the assay's minimum detection level, whereas the T levels of the mock-castrated animal had returned to normal. The rodents were then given their designated injections. In mock-castrated animals, measured $\mathrm{T}$ levels remained around precastrated values

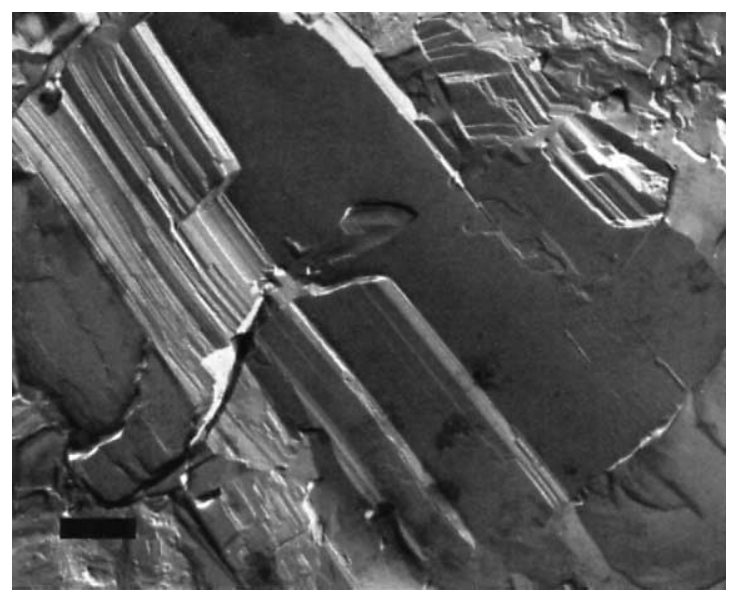

Figure 2. A freeze fracture electron micrograph of ethanol derived TCHARM material (scale bar $375 \mu \mathrm{m}$ ). 
throughout the course of the experiment. The T levels of animals receiving Me4E14 or $1.0 \mathrm{mg}$ T-CHARM remained below the detectablility limit of the assay.

On the other hand, animals receiving $10.0 \mathrm{mg}$ TCHARM had detectable levels of testosterone throughout the course of the experiment (depending on animal) as shown in Table 1. All of these animals had detectable levels of $\mathrm{T}$ on day 2 . The $\mathrm{T}$ levels of two of the six animals exceeded $50 \mathrm{nmol} / \mathrm{L}$, the maximum detection level cutoff. By day 6 , the T levels of both of those animals had dropped below detectable limits; however, a different animal's $\mathrm{T}$ level exceeded the detection maximum, then dropped below the detection limits the following week. The remaining three animals showed elevated $\mathrm{T}$ levels during the course of the experiment but not at such high levels as the previous three animals. Although these results are scattered, one may say that testosterone is released. The release appears to be bolus-like with an initial high concentration of $\mathrm{T}$ in serum exceeding precastration levels with an eventual taper to concentrations below the detectablility limit of the assay used. In order to better define the release kinetics and determine the onset time of a foreign body response (not discussed) an additional animal study was performed.

Table 1. Serum T levels $(\mathrm{nmol} / \mathrm{L})$

\begin{tabular}{lrrrrrrr}
\hline & \multicolumn{7}{c}{ Animal no. } \\
\cline { 2 - 7 } T (nmol/L) & 1 & \multicolumn{1}{c}{2} & \multicolumn{1}{c}{3} & \multicolumn{1}{c}{4} & \multicolumn{1}{c}{5} & \multicolumn{1}{c}{6} \\
\hline Precastration & 6.17 & 9.80 & 13.00 & 20.00 & 15.60 & 32.70 \\
& & & & & & \\
Day 0 Injection Day & $<0.50$ & $<0.50$ & $<0.50$ & 0.77 & $<0.50$ & $<0.50$ \\
Day 2 & 0.54 & $>50.00$ & 1.68 & 0.69 & 0.63 & $>50.00$ \\
Day 6 & 4.17 & 0.98 & $>50.00$ & 0.51 & $<0.50$ & $<0.50$ \\
Day 13 & $<0.50$ & $<0.50$ & $<0.50$ & $<0.50$ & $<0.50$ & $<0.50$ \\
Day 20 & $<0.50$ & $<0.50$ & 0.74 & 15.50 & 0.85 & 13.20 \\
Day 27 & $<0.50$ & $<0.50$ & 0.95 & $<0.50$ & $<0.50$ & 0.63 \\
\hline
\end{tabular}

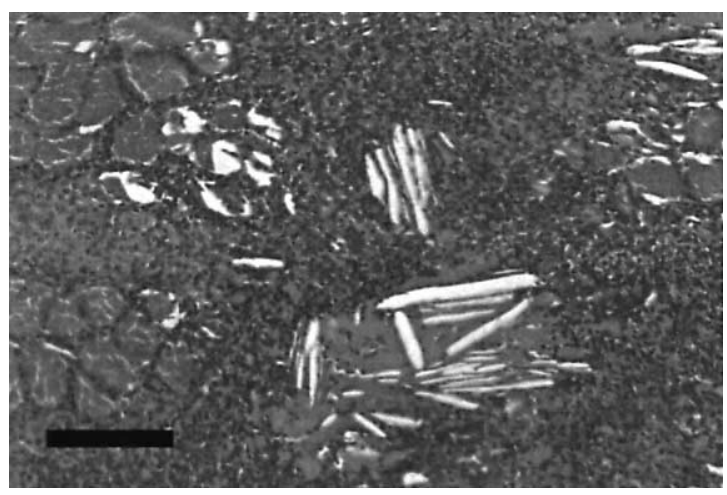

Figure 3. Histological tissue slice from an IM injected rat sacrificed on day 9 (scale bar $100 \mu \mathrm{m}$ ).

Table 2. Serum $\mathrm{T}$ levels $(\mathrm{nmol} / \mathrm{L})$

\begin{tabular}{lcc}
\hline Precastration & SQ injection & IM injection \\
\hline Day 0 (7 days after castration) & $<0.5$ & $<0.5$ \\
30 min postinjection & 37.1 & 9.6 \\
1-9 days postinjection & $<0.5$ & $<0.5$ \\
\hline
\end{tabular}

Study 2. Suspensions of $4.0 \mathrm{mg}$ of T-CHARM material were injected into 10 castrated rats either subcutaneous (SQ) (five animals) or intramuscular (IM) (five animals). Intramuscular injections were used to see if T-CHARM, a lipophilic material, would have a different release profile in a region containing less adipose tissue. Thirty minutes after injection, the testosterone blood levels rose above precastration (normal healthy male rat) values as shown in Table 2 . This result was very surprising in light of the low susceptibility to simple alkaline hydrolysis in vitro. The SQ injection showed a 7 fold higher $\mathrm{T}$ level when compared to noncastrated animals, whereas IM injected animals had less than 2-fold greater T levels; however, within $24 \mathrm{~h}$, the testosterone levels dropped below the minimum detectable limit.

Despite this bolus-like response, there was histological evidence for T-CHARM material being present at the site of injection even after nine days (Fig. 3). In the course of preparing tissue for histological staining, slices were soaked in $70 \%$ ethanol which would dissolve the T-CHARM supramolecular assemblies but leave behind a void in the tissue. The presence of cylindrical voids at the tissue injection sites suggest that some intact $\mathrm{T}$ CHARM material might remain at the site of injection.

In fact, after blending, extracting and examining the remaining tissue, T4E14 was detected. Rough estimates based on the mass of recovered testosterone conjugate and NMR purity suggest that $40 \%$ of the T-CHARM material was still present at the IM injection sites on day nine; however, material was no longer detectable after 27 days in either IM or SQ sites. This implies that the observed testosterone release profile is biphasic, with an early fast release (that is probably not related to simple base-catalyzed hydrolysis of the ester group) followed by a much slower phase of indeterminate length. The relationship between the CHARM morphology, prodrug chemical structures, and the release kinetics in vivo will be the subject of future studies.

\section{Conclusion}

This paper demonstrates that testosterone can be covalently attached via an ester linkage to glutamide core lipid, and the resultant prodrug can form complex high axial ratio microstructures. In vitro, testosterone is released from the CHARMs very slowly under alkaline hydrolytic conditions. In vivo, testosterone release is biphasic with a rapid initial burst followed by a much slower release. This demonstrates the potential of CHARMs to deliver therapeutic agents, even ones with complex structure and hydrophobic nature, for in vivo controlled release.

\section{Experimental}

${ }^{1} \mathrm{H}$ NMR spectra were obtained in $\mathrm{CDCl}_{3}$ using Bruker 500 or $300 \mathrm{MHz}$ spectrometers with tetramethylsilane as an internal standard. The letter ' $T$ ' represents testosterone in the NMR assignments. Silica gel (EM Science 
Silica Gel 60, 230-400 mesh) was used for all flash chromatography. TLC was performed using plates with $250 \mu \mathrm{m}$ Silica Gel $60 \mathrm{~F}_{254}$ (EM Science). Aminoacids were purchased from Bachem. All other chemicals were obtained from Aldrich. All reagents were used as received. Transmission electron micrographs (TEM) were obtained using a Philips EM 410 electron microscope operating at an acceleration potential of $80 \mathrm{kV}$. Samples were applied to Formvar-coated 150 mesh TEM sample grids and stained with $2 \%$ aqueous ammonium molybdate. Molecular modeling was performed using CS Chem 3D Pro software.

Freeze fracture electron microscopy was performed by Nano Analytical Laboratory (San Francisco, CA, USA). Samples were prepared using the sandwich technique and liquid nitrogen-cooled propane. The fracture planes were shadowed in a Balzers BAF 400D device with $\mathrm{Pt}$ for $30 \mathrm{~s}$ at an angle of $25-35^{\circ}$ and with carbon for $35 \mathrm{~s}\left(2 \mathrm{kV} / 60-70 \mathrm{~mA}, 1 \times 10^{-5}\right.$ Torr $)$. The replicas were cleaned using concentrated fuming $\mathrm{HNO}_{3}$ for 24 $36 \mathrm{~h}$.

\section{Synthesis of 2a from 1a}

To BocGlu( $(\mathrm{OtBu}) \mathrm{OSu}(0.313 \mathrm{~g}, 780 \mu \mathrm{mol})$ in $32 \mathrm{~mL}$ $\mathrm{CHCl}_{3}$ was added dodecylamine $(0.151 \mathrm{~g}, 820 \mu \mathrm{mol})$. After stirring overnight, the solution was washed with $20 \mathrm{~mL}$ saturated $\mathrm{NaCl}$ (aq). The aqueous layer was extracted with $20 \mathrm{~mL} \mathrm{CHCl}$. The organic layers were combined and the solvent removed by rotary evaporation. The residue was purified by flash chromatography (30:1-20:1 $\left.\mathrm{CHCl}_{3} / \mathrm{MeOH}\right)$ to provide BocGlu $(\mathrm{OtBu}) \mathrm{C}_{12}$ as an oil $(0.343 \mathrm{~g}, 93 \%): R_{f}\left(9: 1 \mathrm{CHCl}_{3} / \mathrm{MeOH}\right) 0.64 ;{ }^{1} \mathrm{H}$ NMR (300 MHz) $6.98(\mathrm{~s}, 1 \mathrm{H}$, amide), $5.75(\mathrm{~d}, 1 \mathrm{H}, \mathrm{NH})$, 4.17 (bs, 1H, $\alpha), 3.23$ (m, 2H, C-1), $2.33(\mathrm{~m}, 2 \mathrm{H}), 2.04$ $(\mathrm{m}, 1 \mathrm{H}, \beta), 1.94(\mathrm{~m}, 1 \mathrm{H}, \beta), 1.44(\mathrm{~s}, 18 \mathrm{H}, \mathrm{tBu}), 0.88(\mathrm{t}$, $3 \mathrm{H}, \mathrm{C}-12, J=5.9 \mathrm{~Hz})$.

To BocGlu(OtBu $\mathrm{C}_{12}(0.144 \mathrm{~g}, 0.3 \mathrm{mmol})$ in $10 \mathrm{~mL}$ $\mathrm{CHCl}_{3}, 10 \mathrm{~mL} \mathrm{CH}_{2} \mathrm{Cl}_{2}$, and $1 \mathrm{~mL} \mathrm{MeOH}$ was added $15 \mathrm{~mL}$ trifluoroacetic acid. The reaction was stirred for $2 \mathrm{~h}$ upon which an additional $15 \mathrm{~mL}$ of trifluoroacetic acid was added. The solution was stirred for an additional $1.5 \mathrm{~h}$. The solvent was removed by rotary evaporation and the residue purified by flash chromatography $\left(12: 1-8: 1 \mathrm{CHCl}_{3} / \mathrm{MeOH}\right)$ to provide $\mathrm{GluC}_{12}$ as an impure oil (0.186 g: $R_{f}\left(3: 1 \mathrm{CHCl}_{3} / \mathrm{MeOH}\right)$ $0.23 ;{ }^{1} \mathrm{H}$ NMR $(300 \mathrm{MHz}) 4.00(\mathrm{t}, 1 \mathrm{H}, \alpha, J=5.9 \mathrm{~Hz})$, $2.12(\mathrm{t}, 2 \mathrm{H}, J=6.8 \mathrm{~Hz}), 1.81(\mathrm{q}, 2 \mathrm{H}), 1.20(2 \mathrm{H}, \mathrm{C}-2)$, $1.05(\mathrm{t}, 3 \mathrm{H}, \mathrm{C}-12, J=6.8 \mathrm{~Hz})$.

To this impure $\mathrm{GluC}_{12}$ oil residue in $15 \mathrm{~mL}$, dry $p$-dioxane was added triethylamine $(156 \mu \mathrm{L}, 2.1 \mathrm{mmol})$ and ditert-butyldicarbonate $(0.242 \mathrm{~g}, 1.1 \mathrm{mmol})$. The reaction mixture was stirred overnight; then the solvent was removed by rotary evaporation. The residue was purified by flash chromatography $\left(15: 1-8: 1 \mathrm{CHCl}_{3} / \mathrm{MeOH}\right)$ to provide BocGluC $_{12}$ as white solid $(0.073 \mathrm{~g}, 57 \%): R_{f}$ (3:1 $\left.\mathrm{CHCl}_{3} / \mathrm{MeOH}\right) \quad 0.64 ;{ }^{1} \mathrm{H}$ NMR $(300 \mathrm{MHz}) 7.05$ $(1 \mathrm{H}$, amide $\mathrm{NH}), 5.62(1 \mathrm{H}, \mathrm{NH}) 4.28(1 \mathrm{H}, \alpha), 3.22(2 \mathrm{H}$, $\mathrm{C}-1), 2.40(2 \mathrm{H}, \gamma), 1.96(2 \mathrm{H}, \beta), 1.49(2 \mathrm{H}, \mathrm{C}-2), 1.47(\mathrm{~s}$, $9 \mathrm{H}, \mathrm{tBu}), 0.88(\mathrm{t}, 3 \mathrm{H}, \mathrm{C}-12, J=6.8 \mathrm{~Hz})$.
To BocGluC $_{12}(0.147 \mathrm{~g}, 0.36 \mathrm{mmol})$ and testosterone $(0.205 \mathrm{~g}, 0.71 \mathrm{mmol})$ in $10 \mathrm{~mL} \mathrm{CHCl}_{3}$ was added $N$ dimethyl-4-aminopyridine $(0.087 \mathrm{~g}, \quad 0.71 \mathrm{mmol})$ and dicyclohexylcarbodiimide $(0.146 \mathrm{~g}, \quad 0.71 \mathrm{mmol})$. The reaction was stirred overnight. The solution was filtered through glass wool and purified by flash chromatography $\left(25: 1-20: 1 \mathrm{CHCl}_{3} / \mathrm{MeOH}\right)$ to provide BocGlu(testosterone $\mathrm{C}_{12}$ as a light yellow colored oil $(0.177 \mathrm{~g}$, $73 \%): R_{f}\left(3: 1 \mathrm{CHCl}_{3} / \mathrm{MeOH}\right) 0.93 ;{ }^{1} \mathrm{H} \mathrm{NMR}(300 \mathrm{MHz})$ 6.20 (bs, $1 \mathrm{H}$, amide NH), 5.73 (s, 1H, T-4), 5.22 (bs, $1 \mathrm{H}$, $\mathrm{NH}), 4.61(\mathrm{t}, 1 \mathrm{H}, \mathrm{T}-17, J=8.3 \mathrm{~Hz}), 4.07(1 \mathrm{H}, \alpha), 3.25$ (m, 2H, C-1), 2.38-1.90 (m, 8H, $\gamma, \beta, \mathrm{T}-2, \mathrm{~T}-6), 1.63$ (s, $3 \mathrm{H}, \mathrm{T}-19), 1.44$ (s, 9H, tBu), 0.90 (t, 2H, C-12, $J=6.3 \mathrm{~Hz}), 0.83(\mathrm{~s}, 3 \mathrm{H}, \mathrm{T}-18)$.

To BocGlu(testosterone $) \mathrm{C}_{12} \quad(0.78 \mathrm{~g}, \quad 0.26 \mathrm{mmol})$ in $10 \mathrm{~mL} \mathrm{CHCl}$ was added $10 \mathrm{~mL}$ trifluoroacetic acid. The reaction was stirred for $4 \mathrm{~h}$ and then purified by flash chromatography $\left(25: 1-12: 1 \mathrm{CHCl}_{3} / \mathrm{MeOH}\right)$ to provide an oil $(0.119 \mathrm{~g}, 78 \%): R_{f}\left(9: 1 \mathrm{CHCl}_{3} / \mathrm{MeOH}\right) 0.41 ;{ }^{1} \mathrm{H}$ NMR $(300 \mathrm{MHz}) 7.65(\mathrm{bs}, 1 \mathrm{H}$, amide $\mathrm{NH}), 5.74(\mathrm{~s}, 1 \mathrm{H}$, T-4), $4.60(\mathrm{t}, 1 \mathrm{H}, \mathrm{T}-17, J=8.3 \mathrm{~Hz}), 4.60(\mathrm{t}, 1 \mathrm{H}, \mathrm{T}-17$, $J=8.3 \mathrm{~Hz}), 4.17(1 \mathrm{H}, \alpha), 3.26(\mathrm{~d}, 2 \mathrm{H}, \mathrm{C}-1, J=2.4 \mathrm{~Hz})$, 2.51-2.10 (m, 8H, $\gamma, \beta, \mathrm{T}-2, \mathrm{~T}-6), 1.17$ (s, 3H, T-19), $0.86(\mathrm{t}, 3 \mathrm{H}, \mathrm{C}-12, J=6.3 \mathrm{~Hz}), 0.80(\mathrm{~s}, 3 \mathrm{H}, \mathrm{T}-18)$.

\section{Synthesis of $2 \mathrm{~b}$ from $\mathbf{1 b}$}

To BocGlu(OSu)OtBu $(0.221 \mathrm{~g}, 0.55 \mathrm{mmol})$ in $20 \mathrm{~mL}$ $\mathrm{CHCl}_{3}$ was added dodecylamine $(0.245 \mathrm{~g}, 1.32 \mathrm{mmol})$. The reaction was stirred overnight and the solvent removed by rotary evaporation. The residue was purified by flash chromatography (40:1-30:1 $\mathrm{CHCl}_{3} /$ $\mathrm{MeOH})$ to provide BocGlu $\left(\mathrm{C}_{12}\right) \mathrm{OtBu}$ as an oil $(0.248 \mathrm{~g}$, 96\%): $R_{f}\left(9: 1 \mathrm{CHCl}_{3} / \mathrm{MeOH}\right) 0.78 ;{ }^{1} \mathrm{H} \mathrm{NMR}(500 \mathrm{MHz})$ $6.37(\mathrm{~s}, 1 \mathrm{H}), 5.32(\mathrm{~d}, 1 \mathrm{H}, \mathrm{NH}, J=4.0 \mathrm{~Hz}), 4.14(\mathrm{bs}, 1 \mathrm{H}$, $\alpha), 3.23(\mathrm{t}, 2 \mathrm{H}, \mathrm{C}-1, J=6.5 \mathrm{~Hz}), 2.25(\mathrm{t}, 2 \mathrm{H}, \gamma$, $J=6.8 \mathrm{~Hz}), 2.13(\mathrm{bs}, 2 \mathrm{H}, \beta), 1.42(\mathrm{~s}, 18 \mathrm{H}, \mathrm{tBu}), 0.92(\mathrm{t}$, $3 \mathrm{H}, \mathrm{C}-12)$.

To BocGlu $\left(\mathrm{C}_{12}\right) \mathrm{OtBu}(0.248 \mathrm{~g}, 0.53 \mathrm{mmol})$ in $15 \mathrm{~mL}$ $\mathrm{CHCl}_{3}$, and $3 \mathrm{~mL} \mathrm{MeOH}$ was added $15 \mathrm{~mL}$ trifluoroacetic acid. The reaction was stirred for $1.5 \mathrm{~h}$ and the solvent removed by rotary evaporation and the crude oil was dried under vacuum overnight. To the crude material in $25 \mathrm{~mL}$ dry 3:2 $p$-dioxane $/ \mathrm{CHCl}_{3}$ was added triethylamine $(0.164 \mathrm{~g}, 1.6 \mathrm{mmol})$ and di-tertbutyldicarbonate $(0.182 \mathrm{~g}, 832 \mu \mathrm{mol})$. The reaction was stirred overnight and the solvent removed by rotary evaporation. The residue was purified by flash chromatography $\left(20: 1-18: 1 \mathrm{CHCl}_{3} / \mathrm{MeOH}\right)$ to provide Boc$\mathrm{Glu}\left(\mathrm{C}_{12}\right)$ as white solid $(0.101 \mathrm{~g}, 55 \%): R_{f}\left(3: 1 \mathrm{CHCl}_{3} /\right.$ $\mathrm{MeOH})$ 0.82; ${ }^{1} \mathrm{H}$ NMR $(300 \mathrm{MHz}) 6.27$ (bs, $\left.1 \mathrm{H}, \mathrm{NH}\right)$, $5.71(\mathrm{~d}, 1 \mathrm{H}, \mathrm{NH}, J=2.4 \mathrm{~Hz}), 4.25(1 \mathrm{H}, \alpha), 3.25(\mathrm{bs}, 2 \mathrm{H}$, $\mathrm{C}-1), 2.44(\mathrm{~m}, 2 \mathrm{H}, \gamma), 2.10(\mathrm{~m}, 2 \mathrm{H}, \beta), 1.51$ (bs, $2 \mathrm{H}, \mathrm{C}-$ 2), $1.46(\mathrm{~s}, 9 \mathrm{H}, \mathrm{tBu}), 0.86(\mathrm{t}, 3 \mathrm{H}, \mathrm{C}-12, J=6.8 \mathrm{~Hz})$.

To BocGlu $\left(\mathrm{C}_{12}\right)(0.101 \mathrm{~g}, 0.24 \mathrm{mmol})$ and testosterone $(0.105 \mathrm{~g}, 0.36 \mathrm{mmol})$ in $10 \mathrm{~mL} \mathrm{CHCl}_{3}$ was added $\mathrm{N}$ dimethyl-4-aminopyridine $(0.059 \mathrm{~g}, \quad 0.49 \mathrm{mmol})$ and dicyclohexylcarbodiimide $(0.100 \mathrm{~g}, 0.49 \mathrm{mmol})$. After stirring overnight, the cloudy white solution was filtered and the solvent removed by rotary evaporation. The 
residue was purified by flash chromatography (40:1-30:1 $\left.\mathrm{CHCl}_{3} / \mathrm{MeOH}\right)$ to provide BocGlu $\left(\mathrm{C}_{12}\right)$ testosterone as a white solid $(0.063 \mathrm{~g}, 38 \%): R_{f}\left(9: 1 \mathrm{CHCl}_{3} / \mathrm{MeOH}\right) 0.41$; ${ }^{1} \mathrm{H}$ NMR (300 MHz) 7.90 (d, 1H, amide NH), 5.86 (s, $1 \mathrm{H}, \mathrm{T}-4), 5.24(\mathrm{~d}, 1 \mathrm{H}, \mathrm{NH}), 4.60(\mathrm{t}, 1 \mathrm{H}, \mathrm{T}-17), 4.09$ (m, $1 \mathrm{H}, \alpha), 3.25$ (bs, 2H, C-1), $2.44(\mathrm{~m}, 2 \mathrm{H}, \gamma), 2.10(\mathrm{~m}, 2 \mathrm{H}$, $\beta), 1.46(\mathrm{~s}, 9 \mathrm{H}, \mathrm{tBu}), 0.86(\mathrm{t}, 3 \mathrm{H}, \mathrm{C}-12, J=6.8 \mathrm{~Hz})$.

To BocGlu $\left(\mathrm{C}_{12}\right)$ testosterone $(0.0638 \mathrm{~g}, 0.09 \mathrm{mmol})$ in $5 \mathrm{~mL} \mathrm{CHCl}_{3}$ was added $5 \mathrm{~mL}$ trifluoroacetic acid. The reaction was stirred for $3.5 \mathrm{~h}$. The solvent was removed by rotary evaporation and the residue purified by flash chromatography $\left(20: 1-12: 1 \mathrm{CHCl}_{3} / \mathrm{MeOH}\right)$ to provide $\mathrm{Glu}\left(\mathrm{C}_{12}\right)$ testosterone as an oil which turned into a white solid upon drying under vacuum $(0.025 \mathrm{~g}, 46 \%): R_{f}(9: 1$ $\left.\mathrm{CHCl}_{3} / \mathrm{MeOH}\right)$ 0.40; ${ }^{1} \mathrm{H}$ NMR $(300 \mathrm{MHz}) 7.69$ (bs, $1 \mathrm{H}$, amide NH), 5.75 (s, 1H, T-4), 4.58 (t, 1H, T-17, $J=8.1 \mathrm{~Hz}), 4.15(1 \mathrm{H}, \alpha), 3.24(\mathrm{~d}, 2 \mathrm{H}, \mathrm{C}-1, J=2.3 \mathrm{~Hz})$, 2.50-2.08 (m, 6H, $\gamma, \beta, \mathrm{T}-2, \mathrm{~T}-6), 1.16$ (s, 3H, T-19), 0.87 (t, 3H, C-12, $J=6.4 \mathrm{~Hz}$ ), 0.81 (s, 3H, T-18).

\section{Synthesis of 4 from 3}

To testosterone-succinic acid ${ }^{24}$ (3) $(0.098 \mathrm{~g}, 252 \mu \mathrm{mol})$, $\mathrm{Glu}\left(\mathrm{C}_{14}\right)_{2}(0.122 \mathrm{~g}, 227 \mu \mathrm{mol})$ in $30 \mathrm{~mL} \mathrm{CHCl}_{3}$ was added diisopropylethylamine $(70 \mu \mathrm{L}, 402 \mu \mathrm{mol})$ and dicyclohexylcarbodiimide $(0.052 \mathrm{~g}, 252 \mu \mathrm{mol})$. After stirring for $3.5 \mathrm{~h}$ additional dicyclohexylcarbodiimide $(0.052 \mathrm{~g}, 252 \mu \mathrm{mol})$ was added and the solution stirred overnight. The solvent was removed under reduced pressure and the residue purified by flash chromatography $\left(25: 1-20: 1 \mathrm{CHCl}_{3} / \mathrm{MeOH}\right)$ to provide the desired material as a white solid. Impure fractions were repurified (30:1-20:1 $\left.\mathrm{CHCl}_{3} / \mathrm{MeOH}\right)$ and the desired product pooled $(0.162 \mathrm{~g}, 79 \%): R_{f}\left(9: 1 \mathrm{CHCl}_{3} / \mathrm{MeOH}\right) 0.53 ;{ }^{1} \mathrm{H}$ NMR (500 MHz) 7.48 (bs, $\left.1 \mathrm{H} \mathrm{N} \mathrm{N}_{\mathrm{T}} \mathrm{NH}\right), 7.01$ (bs, $1 \mathrm{H}$, $\left.\mathrm{C}_{\mathrm{T}} \mathrm{NH}\right), 6.12$ (bs, $1 \mathrm{H}$, side-chain $\left.\mathrm{NH}\right), 5.73$ (s, $\left.1 \mathrm{H}, \mathrm{T}-4\right)$, $4.56(\mathrm{t}, 1 \mathrm{H}, \mathrm{T}-17, J=8.0 \mathrm{~Hz}), 4.37(\mathrm{~m}, 1 \mathrm{H}, \mathrm{a}), 3.22(\mathrm{~m}$, 4H, C-1), 1.19 (s, 3H, T-19), 0.88 (t, 6H, C-14, $J=6.8 \mathrm{~Hz}), 0.83(\mathrm{~s}, 3 \mathrm{H}, \mathrm{T}-18)$.

\section{Formation and incorporation of testosterone or testosterone conjugates in CHARMs}

Intimate mixtures of $\mathrm{T}$ or AcT and $\mathrm{E} 12$ or AcE12 were initially dissolved in EtOH or DMF. Sufficient water was then added to bring the final lipid concentration to $1 \mathrm{mg} / \mathrm{ml}$ and have a water-to-organic solvent ratio of 70:30. After sitting overnight, the cloudy white heterogeneous suspensions were pelleted $\left(20,000 \mathrm{~g}, 10^{\circ} \mathrm{C}\right.$, $10 \mathrm{~min}$ ) and the supernatant removed. Both supernatant and pellet were dried under vacuum for at least $2.5 \mathrm{~h}$. The fractions were then dissolved in $\mathrm{CDCl}_{3}$ and examined by ${ }^{1} \mathrm{H}$ NMR. The ratio of $\mathrm{T}$ (or AcT) to E12 (or AcE12) was evaluated by comparison of the integrand for the T-4 vinyl proton $(\delta 5.7,1 \mathrm{H})$ versus that of the $\alpha$ carbon of the alkyl chain(s) $(\delta 3.2,2 \mathrm{H}$ or $4 \mathrm{H}$ depending on the presence of one or two alkyl sidechains).

\section{In vitro hydrolysis}

A known mass of lipid in CHARM form was pelleted $\left(20,000 \mathrm{~g}, 10^{\circ} \mathrm{C}, 10 \mathrm{~min}\right)$, the supernatant removed and replaced with an equal volume of $100 \mathrm{mM} \mathrm{NaH}_{2} \mathrm{PO}_{4}$ at $\mathrm{pH}$ 9.2. After repeating three times, CHARMs were incubated at $37^{\circ} \mathrm{C}$ in closed tubes. At various times, the CHARMs were pelleted (as before) and the supernatant removed. The pellets and supernatants were dried under vacuum for at least $2.5 \mathrm{~h}$, dissolved in $\mathrm{CDCl}_{3}$ and examined by ${ }^{1} \mathrm{H}$ NMR. The extent of hydrolysis was determined by comparing the integrand ratio of free testosterone T-17 ( $\delta 3.62)$ to T4E14's T-17 ( $\delta 4.56)$. In all cases, the supernatant fraction did not contain detectable amounts of lipid.

\section{In vivo experimental}

Study 1. Eighteen male Sprague-Dawley 16-week-old rats (average weight $275 \mathrm{~g}$, Charles River, Boston, MA, USA) were anesthetized with inhaled enflurane and underwent bilateral orchiectomy (castration) using sterile technique. In addition, six male Sprague-Dawley 16week-old rats (average weight $275 \mathrm{~g}$, Charles River, Boston, MA, USA) were also anesthetized with inhaled enflurane and underwent mock castration using sterile technique. Prior to castration, $0.5 \mathrm{~mL}$ of blood was collected from each animal by tail bleeding. All blood samples were processed by Ficoll-Hypaque density centrifugation $(10 \mathrm{~min}, 1400 \mathrm{~g})$ to obtain serum, which was stored at $-4{ }^{\circ} \mathrm{C}$ until assayed for testosterone. The animal's weights were followed during the course of the experiment and all animals gained weight during the experiment with up to a $30 \%$ weight increase by the end, which is an indicator of good health.

Seven days after castration, the animals were again anesthetized and received subcutaneous abdomen injections with $10.0 \mathrm{mg}$ T-CHARM in $3.0 \mathrm{~mL}$ sterile PBS pH 7.4 (six animals), $1.0 \mathrm{mg}$ T-CHARM in $0.3 \mathrm{~mL}$ sterile PBS pH 7.4 (six animals), $3 \mathrm{~mL}$ sterile PBS pH 7.4 (six mock castrated animals) or $10 \mathrm{mg}$ Me4E14 in $3 \mathrm{~mL}$ sterile PBS pH 7.4 (six animals) using a 19-gauge needle. Animals underwent tail bleed immediately prior to $\mathrm{T}$ CHARM injection and on days 2, 6, 13, 20, and 27 after injection at which time they were sacrificed by decapitation. Testosterone serum levels were detected using a time-resolved immunofluorimetric assay (DELFIA ${ }^{30}$ ) and compared against standard concentrations. The inter- and intra-assay coefficients of variation were 4.1 and $8.1 \%$, respectively.

Study 2. Methods were similar to Study 1 except that 10 male Sprague-Dawley 16-week-old rats were employed. The animals' weights were followed for 2 weeks (7 days precastration to 0-9 days postcastration). All animals gained weight during the experiment with up to a $20 \%$ weight increase by the end, which is an indicator of good health.

Seven days after castration, the animals were again anesthetized and injected with $4.0 \mathrm{mg}$ of T-CHARM (containing $1.3 \mathrm{mg}$ of $\mathrm{T}$ ) in $300 \mathrm{~mL}$ of sterile PBS pH 7.4. Five animals received subcutaneous abdominal injections and five received injections intramuscularly in the large quadriceps muscle of the right hind thigh. All animals were tail bled immediately prior to T-CHARM 
injection to establish basal serum T-levels (which were below the $0.5 \mathrm{nmol} / \mathrm{L}$ minimum detection threshold). Daily $\mathrm{T}$-serum levels were determined from tail bleeds according to the following schedule:

Time No. of animals blood drawn from:

\begin{tabular}{lll}
\hline & SQ & IM \\
\hline 30 min & 1 & 1 \\
Day 1 & 2 & 2 \\
Day 2 & 2 & 2 \\
Day 3 & 3 & 2 \\
Day 4 & 1 & 2 \\
Day 5 & 2 & 2 \\
Day 6 & 1 & 1 \\
Day 7 & 1 & 2 \\
Day 8 & 1 & 0 \\
Day 9 & 1 & 1 \\
\hline
\end{tabular}

Testosterone serum levels were detected using a timeresolved immunofluorimetric assay $\left(\right.$ DELFIA $\left.^{30}\right)$ and compared against standard concentrations. The interand intra-assay coefficients of variation were 4.1 and $8.1 \%$, respectively.

\section{Determination of residual T-CHARM material near injection site}

Approximately $10 \mathrm{~g}$ of tissue was resected from around the injection area, which was identified by palpation. Tissue was immediately preserved in buffered formalin until analysis. A 1-cm margin around the palpable area was resected to insure inclusion of all injected materials. Histological slices were fixed overnight in $70 \%$ ethanol before sequential dehydration to xylene in an LX 300 Tissue Processor (Fisher Scientific) and embedded in paraffin. Paraffin sections were cut, transferred to glass slides and stained with hexatoxylin and eosin.

The remaining untreated tissue was blended and the lipids extracted with ethanol and chloroform. The crude lipid extracts were further fractionated by silica gel flash chromatography to remove nonpolar lipids such as cholesterol and more polar charged phospholipids. Three of the 14 semi-purified fractions contained T4E14 material as determined by thin layer chromatography. Further verification was provided by ${ }^{1} \mathrm{H} \quad \mathrm{NMR}$ confirming the presence of T4E14.

\section{Acknowledgements}

This work was supported by a grant from the Whitaker Foundation to PY and Veteran's Administration Medical Research Funds. The authors thank Dr. Anatoly Lukyanov for mouse and needle images.

\section{References and Notes}

1. Wilson, J. D. Androgens. In Goodman and Gilman's Pharmacological Basis of Therapeutics, 9th ed.; Hardman, J. G., Limbird, L. E., Gilman, A. G., Eds.; McGraw-Hill: USA, 1996.

2. Drug Ther. Bull. 1985, 23, 7

3. Kamischke, A.; Ploger, D.; Venherm, S.; von Eckardstein, S.; von Eckardstein, A.; Nieschlag, E. Clin. Endocrinol. (Oxf) 2000, 53, 43 .

4. Amory, J. K.; Matsumoto, A. M. Exp. Opin. Invest. Drugs 1998, 7, 1977.

5. Drug Ther. Bull. 1999, 37, 3

6. Shen, Z. R.; Zhu, J. H.; Ma, Z.; Wang, F.; Wang, Z. Artif. Cells Blood Substit. Imobil. Biotechnol. 2000, 28, 57.

7. Tsubuku, S.; Sugawara, S.; Miyajima, M.; Yoshida, M.; Asano, M.; Okabe, K.; Kobayashi, D.; Yamanaka, H. Drug. Dev. Ind. Pharm. 1998, 24, 927.

8. Ravivarapu, H. B.; Moyer, K. L.; Dunn, R. L. Int. J. Pharm. 2000, 194, 181.

9. Stokes, K. I.; Benguzzi, H. A.; Cameron, J. A. Biomed. Sci. Instrum. 2000, 36, 209.

10. Gould-Fogerite, S.; Edghill-Smith, Y.; Kheiri, M.; Wang, Z.; Das, K.; Feketova, E.; Canki, M.; Mannino, R. J. AIDS Res. Hum. Retroviruses 1994, 10, S99.

11. Mannino, R. J.; Canki, M.; Feketova, E.; Scolpino, A. J.; Wang, Z.; Zhang, F.; Kheiri, M. T.; Gould-Fogerite, S. Adv. Drug Del. Rev. 1998, 32, 273.

12. Schnur, J. M.; Price, R.; Rudolph, A. S. J. Control. Release 1994, 28, 3.

13. Sprago, B. J.; Cliff, R. O.; Rollwagen, F. M.; Rudolph, A. S. J. Microencapsul. 1995, 12, 247.

14. Lee, K. C.; Carlson, P. A.; Goldstein, A. S.; Yager, P.; Gelb, M. H. Langmuir 1999, 15, 5500.

15. Lee, K. C.; Lukyanov, A. N.; Gelb, M. H.; Yager, P. Biochim. Biophys. Acta 1998, 1371, 168.

16. Shimizu, T.; Hato, M. Biochim. Biophys. Acta 1993, 1147, 50 .

17. Carlson, P. A.; Gelb, M. H.; Yager, P. Biophys. J. 1997, 73, 230.

18. Goldstein, A. S.; Yager, P.; Gelb, M. H. J. Control. Rel. 2001, 70, 125.

19. Goldstein, A. S.; Lukyanov, A. N.; Carlson, P. A.; Yager, P.; Gelb, M. H. Chem. Phys. Lipids 1997, 88, 21.

20. Yu, K.; Eisenberg, A. Macromolecules 1998, 31, 3509.

21. Melia, T. J.; Sowa, M. E.; Schutze, L.; Wensel, T. G. J. Struct. Biol. 1999, 158, 119.

22. Wilson-Kubalek, E. M.; Brown, R. E.; Celia, H.; Milligan, R. A. Proc. Natl. Acad. Sci. U.S.A. 1998, 95, 8040.

23. Zhang, G. Y.; Gu, Y. Q.; Wang, X. H.; Cui, Y. G.; Bremner, W. J. Clin. Endrocrinol. Metab. 1999, 84, 3642.

24. Scriba, G. K. E. Arch. Pharm. (Weinheim) 1995, 328, 271. 25. Archibald, D. D.; Yager, P. Biochemistry 1992, 31, 9045.

26. Archibald, D. D.; Mann, S. Biochim. Biophys. Acta 1993, 1166, 154.

27. Archibald, D. D.; Yager, P. Chem. Phys. Lipids 1994, 69, 51.

28. Fuhrhop, J.; Schnieder, P.; Boekema, E.; Helfrich, W. J. J. Am. Chem. Soc. 1988, 107, 12515.

29. Yu, Y. C.; Berntdt, P.; Tirrell, M.; Fields, G. B. J. Am. Chem. Soc. 1996, 118, 12515.

30. Boettcher, C.; Stark, H.; van Heel, M. Ultramicroscopy 1996, 26, 133.

31. Goldstein, A. S.; Gelb, M. H.; Yager, P. Chem. Phys. Lipids 2001, 109, 1.

32. Gruenewald, D. A.; Naii, M. A.; Marck, B. T.; Matsumoto, A. M. J. Androl. 2000, 21, 72. 